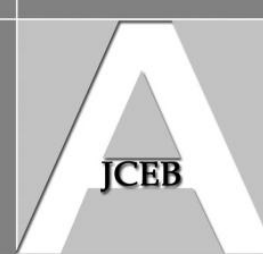

\title{
Managing Geotechnical Risk on US Design-Build Transport Projects
}

\author{
Kevin McLain, (Missouri Department of Transportation, USA)
}

Douglas Gransberg, (lowa State University, USA)

Micheal Loulakis, (Capital Project Strategies, LLC, USA)

\begin{abstract}
Awarding design-build (DB) contracts before a complete subsurface investigation is completed, makes mitigating the risk of differing site conditions difficult, if not impossible. The purpose of the study was to identify effective practices for managing geotechnical risk in DB projects, and it reports the results of a survey that included responses from 42 of 50 US state departments of transportation and a content analysis of DB requests for proposals from 26 states to gauge the client's perspective, as well as 11 structured interviews with DB contractors to obtain the perspective from the other side of the DB contract. A suite of DB geotechnical risk manage tools is presented based on the results of the analysis. Effective practices were found in three areas: enhancing communications on geotechnical issues before final proposals are submitted; the use of project-specific differing site conditions clauses; and expediting geotechnical design reviews after award. The major finding is that contract verbiage alone is not sufficient to transfer the risk of changed site conditions. The agency must actively communicate all the geotechnical information on hand at the time of the DB procurement and develop a contract strategy that reduces/retires the risk of geotechnical uncertainty as expeditiously as possible after award.
\end{abstract}

Keywords: Design-build, Geotechnical uncertainty, Risk management, Transport, Construction.

\section{Introduction}

"Geotechnical engineering is fundamentally about managing risk" (Ho et al., 2000). Managing the risk of geotechnical site conditions is never simple; however, when a DB (also termed "design and build" in many countries) contract is awarded before a complete subsurface investigation is complete; it becomes even more difficult (Perkins, 2009). In the US, recent government pressure to expedite the delivery of highway construction projects to address the current infrastructure deterioration crisis has created a procurement environment where DB projects are being awarded as soon as environmental consents can be obtained without regard to the potential impact of failing to quantify and mitigate geotechnical risk on post-award project cost and schedule (Mendez, 2010; Hatem, 2011; Federal, 2013).

The US Federal Highway Administration's (FHWA) Special Experimental Projects No. 14 Alternative Contracting (SEP-14) was introduced in 1990 and by 2009 had authorized over 400 DB highway projects (Federal, 2006). A decade later, the FHWA announced its "Every Day Counts" (EDC) initiative to address the rapid renewal of the nation's rapidly deteriorating infrastructure. The program is designed to accelerate the implementation of innovative practices that are immediately available as described by the current FHWA Administrator, Victor Mendez.

"Our society and our industry face an unprecedented list of [infrastructure] challenges. Because of our economy, we need to work more efficiently... But it's not enough to simply address those challenges. We need to do it with a new sense of urgency. It's that quality - urgency — that l've tried to capture in our initiative, Every Day Counts." (Mendez, 2010; italics added). 
Replacing traditional design-bid-build (DBB) with DB project delivery is one of the tools being specifically encouraged by the EDC program. A report to the US Congress on the effectiveness of DB in highway construction reviewed every project authorized under SEP-14 and found that on average DB "reduced the overall duration of their projects by 14 per cent, reduced the total cost of the project by 3 per cent, and maintained the same level of quality as compared to DBB" (Federal, 2006). The same report also concluded that clients select DB primarily as a means to accelerate a project's schedule, validating a trend reported nearly a decade earlier by Songer and Molenaar (1996). Higbee (2004) found that the major hurdle to achieving an accelerated schedule in DB is the client's approval to release the design for construction. The geotechnical investigation and subsequent foundation design is often the first design package that must be released. Since geotechnical uncertainty is often high at the time of DB contract award, the design-builder's geotechnical designers are under pressure to complete their work as quickly as practical to allow foundation and other subsurface construction to begin.

The 2006 Report to Congress found that less than 3 per cent of total highway projects were delivered using DB (Federal, 2006) and, because DB transport projects could only be delivered after obtaining FHWA permission via the SEP-14 application process, the overall impact of managing geotechnical risk has been low on a nation-wide, programmatic basis. DB contracting could not be described as a "routine" method to deliver construction projects. That changed in 2007 when the FHWA DB contracting "final rule" was ratified by the US Congress (Federal, 2007), making it fully eligible for delivering federally-funded projects. The impact was profound with the number of states authorized by their own state legislatures to use DB growing from 33, at the time of the 2006 Report to Congress, to 47 today (Design 2013). The growth in DB usage was further spurred in 2012 by the passage of Public Law 112-141, the Moving Ahead for Progress in the $21^{\text {st }}$ Century Act (MAP-21), which reduced the state funding share of federal-aid highway projects delivered using DB from 10 per cent to 5 per cent (Federal 2013). Thus, a substantial financial incentive has been provided to state transport agencies that have previously chosen not to implement DB. The political pressure to implement DB is further increased by the FHWA EDC program objective of increasing the number of projects delivered using DB by $50 \%$ by 2014 (Mendez, 2010).

From the public agency geotechnical engineer's perspective, the net result will be to increase the number of DB projects awarded before subsurface investigations are complete. From the design-builder's perspective, increased geotechnical risk will translate into higher contingencies included in proposed prices to mitigate those risks from the contractor's perspective (Christensen and Meeker, 2002). Higher prices translate to higher potential that the agencies will ultimately not have sufficient budget to actually award the DB project once the proposals have been opened. Therefore, successfully managing the geotechnical risk during the procurement phase of a DB project becomes essential to being able to award the given project within its budget (Clark and Borst, 2002). Accordingly, the researchers address the following questions:

- What measures can a public transport agency take to manage geotechnical risk during the DB procurement process?

- What can be done after the award of the DB contract to mitigate and retire geotechnical risk in an expeditious manner?

The answers to these questions found in the study are synthesized into a set of geotechnical risk management tools that can be used by public clients to better allocate geotechnical risk among DB project stakeholders. Additionally, the authors provide construction procurement researchers a platform from which to support future research on optimizing DB procurement risk with the need to accelerate project delivery of transport projects.

McLain, K et al (2014) 'Managing geotechnical risk on US design-build transport', Australasian Journal of Construction Economics and Building, 14 (1) 1-19 


\section{Background}

The current emphasis on accelerated project delivery in the US creates an environment where public engineers may be forced to focus on expediting the procurement process rather than fully developing the project's geotechnical requirements. This includes evaluating how much of the geotechnical investigation should be done by the design-builder after contract award. The geotechnical investigation decision has a number of ramifications, including the level of liability for the underground conditions that can be transferred along with the geotechnical investigation and design responsibility for the foundation/subsurface design.

\section{Risk-based Geotechnical Design}

The FHWA introduced risk-based geotechnical design in 1987 when it published the Geotechnical Risk Analysis User's Guide developed by G.B. Baecher. This document moved geotechnical design on federally-funded highway projects away from a set of "conservative factors of safety" and toward modelling uncertainty on a project-specific basis via a statistically determined reliability index. This shift was necessary because a "fixed factor of safety implies a different likelihood of failure" in each project and creates a situation where "the overall factor of safety in a design is unknown" (Baecher, 1987). Baecher's work assumed that the project would be delivered using DBB project delivery and the data used as input for the risk-based design would spring from a thorough program of geotechnical investigation, testing, and analysis. An Australian study of the implications of inadequate site investigations agreed with Baecher's assertion regarding communicating geotechnical uncertainty and recommended that geotechnical uncertainty be expressed using statistical measures such as confidence limits. Jaksa (2002) argues that doing so permits "any other engineer utilizing these values, as well as the client, to appreciate the uncertainty associated with the parameters and, hence, appropriately account for them in the design process." The ability to understand the amount of as-designed geotechnical risk is one key to effectively managing that risk after award. A critical discourse on the subject of quantifying geotechnical risk in the design asserted that "designers sometimes wishfully classify those factors which they cannot confidently characterize as being of minor importance, or hope that such imponderables would be compensated by conservatism built in the system elsewhere" (Ho et al., 2000). This notion also agrees Baecher's findings regarding the weakness of using fixed factors of safety. Ho et al. go on to advocate the use of quantitative risk assessment in conjunction with traditional deterministic methods to better communicate geotechnical risk throughout the project's design and construction process. Van Straveren (2000) builds on the quantitative risk analysis theme and extends the argument to actively managing geotechnical risk across a project's entire life cycle with a focus on articulating risk during procurement and cited a "1:10 cost-benefit ratio...as a result of better contracting practices by improved risk allocation."

Oberguggenberger and Fellin (2002) take an opposing view of the value of statistically-based geotechnical risk analysis. Their opinion is founded in theoretical mathematics rather than geotechnical engineering design. While they recognize the role of failure probabilities and safety factors in comparative analysis of design options, they state that "these numerical values do not make quantitative assertions about reality... the failure probability cannot be interpreted as a frequency of failure." While their proof of the superiority of fuzzy sets over probability-based risk analysis appears to be eloquent, it is also arcane requiring an understanding of mathematics at a level beyond the academic preparation of most practicing geotechnical engineers, an argument made by Ho et al. (2000). Those authors contended that resistance to the increased knowledge required to move from deterministic to probabilistic geotechnical risk analysis, much less fuzzy set theory, "is by no means easy to resolve... [requiring] appropriate grounding of the basic concepts [of statistical risk analysis] in university education and focused professional training..." Thus, while Oberguggenberger and Fellin's approach may produce a better means

McLain, K et al (2014) 'Managing geotechnical risk on US design-build transport', Australasian Journal of Construction Economics and Building, 14 (1) 1-19 
to model geotechnical uncertainty, it must be regarded as impractical due to the need to educate a significant number of engineers, an idea supported by Baynes (2010).

Baynes plays heavily on the human factor and finds that total geotechnical risk is a combination of the technical conditions and the competence of the project staff. In fact, "the project staff may actually be the largest source [of risk]." Baynes emphasizes the need to educate and train project staff to "manage and mitigate the geotechnical risks, rather than generate them." He, like van Straveren (2000), also stresses the need to manage geotechnical risk throughout the project's life cycle, specifically identifying the procurement phase as a point where "inadequate understanding of the importance of ground conditions results in poor acquisition... [that] leads to claims based on contractually unforeseen ground conditions" (Baynes, 2010). To summarize the literature, geotechnical risk management is more than the use of sophisticated statistical models to quantify the risk in probabilistic terms. It must be continually evaluated as an integral part of the project development decision-making process (Baecher, 1987; Ho et al., 2000; van Staveren, 2000; Baynes, 2010). All of the above literature was written in the DBB context where the procurement was based on a completed geotechnical design that was in turn based on subsurface investigation. The issue of subsurface risk becomes weightier when the geotechnical investigation moves from being a condition precedent to DBB construction contract award to a deliverable required after award of a DB contract.

\section{Design-build Contracting}

DB project delivery has proven itself to be one method to accelerate the construction, reconstruction, and rehabilitation of aging, structurally deficient infrastructure (Federal, 2006). DB also allows the public transport agency to shift some of the responsibility for completing the geotechnical investigations necessary to support the geotechnical design to the design-builder after the award of the DB contract. This creates a different risk profile than when the project client has full responsibility for design (and hence geotechnical investigations) in a traditional DBB project (Loulakis et al., 1995).

The FHWA mandates the use of a Differing Site Conditions (DSC) clause for DBB projects on federal aid highway projects, unless the use of such a clause is contrary to state law (Loulakis et al., 1995). The DSC clause provides broad relief to a contractor for physical conditions that materially differ from what is anticipated by the contract. FHWA does not, however, have the same mandate for DB projects. Instead, FHWA encourages state DOTs to use these clauses when appropriate for the risk and responsibilities that are shared with the design-builder.

On DBB projects, the risk of differing site conditions is almost always the responsibility of the client (Tufenkjian, 2007), based on the contract's DSC clause and prevailing case law (Higbee, 2004). Diekmann, et al. (1987) confirmed this point specifically for infrastructure projects. On DB projects, the risk of differing site conditions is not as clear (Clark and Borst, 2002). The DB contract can be awarded before a full geotechnical site investigation is made by either the client or the winning design-builder (Smith, 2008). This leads to a question of how to identify an appropriate reference point for implementing the DSC clause if one is included in the contract (Hatem, 2011). There is also a policy question for the agency as to how much information it should furnish about the geotechnical site conditions (Blanchard, 2007; Dwyre et al., 2010). The more information that is provided, the more likely it is that the design-builder can submit a competitive price proposal since it is able to reduce the contingencies contained in the price proposal for geotechnical uncertainty (Christensen and Meeker, 2002). Additionally, this will enable the agency to have a better sense of its program and expected costs. However, because the DB delivery method has proven to be an effective means of compressing project delivery periods to their shortest states (FHWA, 2006), there is frequently an incentive for the

McLain, K et al (2014) 'Managing geotechnical risk on US design-build transport', Australasian Journal of Construction Economics and Building, 14 (1) 1-19 
agency to start the procurement process before a robust geotechnical program has been performed (Higbee, 2004; Kim et al., 2009).

\section{Pre-award Geotechnical Risk Distribution}

Given the above, an agency should first address whether or not a given project is a good candidate for DB project delivery in the context of the geotechnical conditions' impact on the preliminary design, price, and time. Table 1 is a synopsis of the risk profiles for DBB and DB found in Koch et al. (2010) and adapted for geotechnical risks. One can see that the major change in the risk profile is due to the shift in design responsibility to the design-builder. The client's new DB risks result in many cases from failing to relinquish the design responsibility to the design-builder. The client's DB scope risk for geotechnical design review comments and/or directives is an example of this. Direct and tacit approval of constructive changes to the geotechnical design during construction is another example.

\begin{tabular}{|c|c|c|}
\hline & Contractor/Design-Builder & Client \\
\hline & \multicolumn{2}{|c|}{ Geotechnical Scope Risk } \\
\hline DBB & $\begin{array}{l}\text { - Warranties and Guarantees } \\
\text { - Latent Defects - Workmanship } \\
\text { - Competent Geotechnical } \\
\text { Construction Personnel Available }\end{array}$ & $\begin{array}{l}\text { - Design Error and Omissions } \\
\text { - Latent Defects - Design } \\
\text { - Direct \& Tacit Approval of Constructive Changes to } \\
\text { Design }\end{array}$ \\
\hline \multirow[t]{2}{*}{ DB } & $\begin{array}{l}\text { - Design Errors \& Omissions } \\
\text { - Warranties \& Guarantees } \\
\text { - Latent Defects - Design \& } \\
\text { Workmanship } \\
\text { - Competent Geotechnical Design } \\
\text { Personnel Available }\end{array}$ & $\begin{array}{l}\text { - Clear Geotechnical Scope Definition } \\
\text { - Direct \& Tacit Approval of Constructive Changes to } \\
\text { Geotechnical Design } \\
\text { - Geotechnical Design Review Comments \& } \\
\text { - Directives } \\
\text { - Technical Review Capability }\end{array}$ \\
\hline & \multicolumn{2}{|c|}{ Geotechnical Cost Risk } \\
\hline DBB & $\begin{array}{l}\text { - Rework } \\
\text { - Subcontractor Default } \\
\text { - Market Fluctuation after Award }\end{array}$ & $\begin{array}{l}\text { - Redesign and Resultant Rework } \\
\text { - Construction Contract Amount } \\
\text { - Market Fluctuation During Design - Material \& Labor }\end{array}$ \\
\hline \multirow[t]{2}{*}{ DB } & $\begin{array}{l}\text { - Redesign \& Rework } \\
\text { - Subcontractor Default } \\
\text { - Market Fluctuation During Design - } \\
\text { Material \& Labor }\end{array}$ & $\begin{array}{l}\text { - Design-Build Contract Amount } \\
\text { - Prompt Payment } \\
\text { - Design-Builder Default }\end{array}$ \\
\hline & \multicolumn{2}{|c|}{ Geotechnical Schedule Risk } \\
\hline DBB & $\begin{array}{l}\text { - Contract Completion Date } \\
\text { - Liquidated Damages }\end{array}$ & $\begin{array}{l}\text { - Timely Design Completion } \\
\text { - Client Furnished Property Delivery }\end{array}$ \\
\hline DB & $\begin{array}{l}\text { - Delivery on Approved Schedule } \\
\text { - Fast-Track Geotechnical Rework } \\
\text { - Liquidated Damages }\end{array}$ & $\begin{array}{l}\text { - Unrealistic Schedule } \\
\text { - Timely Geotechnical Design Approvals Client } \\
\text { Furnished Property Delivery }\end{array}$ \\
\hline
\end{tabular}

Table 1 DBB versus DB risk profiles

Hatem (2011) maintains that DB geotechnical uncertainty "is always high until the post-award site investigation and geotechnical design report can be completed." The geotechnical/site engineering is the first major design package that must be released to get construction started (Higbee 2004) and competing design-builders must base their schedule estimates on expeditiously completing this key design task (Centennial, 2004). Given the criticality of the geotechnical investigation and design to DB project success, the inclusion of proposal evaluation criteria specifically addressing the competing proposers' approach to project

McLain, K et al (2014) 'Managing geotechnical risk on US design-build transport', Australasian Journal of Construction Economics and Building, 14 (1) 1-19 
geotechnical issues, ensures that the competing design-builders will focus on those aspects of the project in the proposal because if they do not, their proposal will be found to be nonresponsive (Higbee, 2004).

The Washington State DOT (WSDOT) Guidebook for Design-Build Highway Project Development (2004) maintains that the agency is "responsible for establishing the scope, project definition, design criteria, performance measurements, and existing conditions of the site (initial geotechnical investigation, subsurface conditions)." The responsibilities listed in this passage form a foundation for determining what specific data should be included in the DB RFP. This agency agrees with Hung et al. (2009) and goes on to elaborate that "it is necessary for WSDOT to establish a baseline for design-builders to develop their technical and price proposals" and that "preliminary geotechnical investigations will be conducted by WSDOT with data provided to Proposers."

WSDOT is consciously creating an environment of open communication regarding geotechnical uncertainty and allocating differing site conditions risk. In fact, the document states: "Ultimately, WSDOT will own responsibility for Changed and Differing Site Conditions." Since the geotechnical portion of a DB contract is the combination of information contained in the RFP and the winning proposal (Koch et al., 2010), the amount of geotechnical information contained in the RFP effectively creates the baseline from which a DSC is applied.

\section{Design-build Contract Pricing}

The predominant way that $\mathrm{DB}$ is procured in the public sector requires that the design-builder commit to a firm fixed price before the project's geotechnical design is complete (Mahdi and Alreshaid, 2005). Thus, the risk of cost overruns for unforeseen geotechnical site conditions is increased since the geotechnical investigations necessary for each project will likely be completed after contract award, during the design process. Some public clients have the view that using DB shifts the full risk of differing site conditions to the contractor (Christensen and Meeker, 2002). The basic flaw in this approach is that contractors cannot accurately value the risk of geotechnical uncertainty before a thorough site investigation is completed. If they are forced to price the risk, they will include contingencies that may either price themselves out of the procurement or, if they do win the contract, be insufficient for addressing actual conditions, further intensifying the bias to inflate the contingency. Many sophisticated contractors will simply refuse to compete for a contract where they have unlimited risk of differing site conditions (Centennial, 2004; Loulakis et al., 1995), and $90 \%$ of the design-builders interviewed stated that the amount of detail available in the RFP had an impact on project quality. Following the recommendations made by Hung et al. (2009) effectively limits both the contractor's and the client's risk. The client only pays for the actual costs incurred if and when these conditions are actually encountered, as opposed to the unliquidated contingency for a problem that may never emerge.

All of this creates potential risks to both parties that are not present in a DBB delivery process (Washington, 2004). In a technical sense there is a wide spectrum of potential geotechnical risks, but in DB procurement, there is only one: actual conditions will materially differ from those upon which the project's price was predicated.

\section{Method and Methodology}

The researchers used qualitative comparative analysis as the overarching research method to leverage its ability "to blend the in-depth knowledge obtained from small-N studies of cases with the inferential power of statistical large- $\mathrm{N}$ studies...[and] determine causal relationships between 'causal conditions' (similar to independent variables) and 'outcome conditions' (similar 
to dependent variables)" (Jordan et al., 2011). Specifically, the researchers conducting this study needed to compare case study contractor interview output with the output from a survey and the content analysis of DB procurement documents. Since the study topic was inherently a variable mixture of technical geotechnical engineering and the legalistic construction procurement process, this relatively new approach was selected to lend rigor to the research protocol. Three research instruments formed the study's data collection plan.

First, a review of the literature on DB contracting with a focus on geotechnical risk was completed. Both US and international documents were searched. The literature was then used to develop the content of an on-line survey of US DOTs. The survey questionnaire was designed using the principles prescribed by Oppenheim (1992) for survey questionnaire design. The researcher's underlying hypothesis for the survey was:

Geotechnical risk varies inversely with the amount of site-specific geotechnical information that is provided to competing design-builders during procurement.

\section{DOT Survey}

Since the research was sponsored by the American Association of State Highway and Transportation Officials (AASHTO) and funded by the National Academies' National Cooperative Highway Research Program (NCHRP), the survey was issued to the members of the AASHTO Subcommittees on Construction and Design in each of the 50 US state DOTs. The subcommittee members were asked to forward the survey to the person best-qualified to respond from an overall departmental basis. Responses were received from 42 DOTs yielding an overall response rate of $84 \%$. Table 2 shows the locations of the respondents and their positions at the time of the questionnaire. The table shows that the survey received responses from a cross-section of senior engineers with design-build experience. Design professionals made up roughly $60 \%$ of the response for those DOTs that use DB. The rest were either construction field personnel or DB project managers. Hence, the collective response from the sample covers the entirety of DB project delivery from planning through construction completion and administrative/legal close-out.

\section{Procurement Document Content Analysis}

The second instrument was a content analysis performed on DB procurement documents from 26 states in addition to DB policy documents/guidelines from 12 state DOTs and 5 federal agencies. This type of analysis can be used to develop "valid inferences from a message, written or visual, using a set of procedures" (Neuendorf 2002). The primary approach is to develop a set of standard categories into which words that appear in the text of a written document, in this case a DB procurement or policy document, can be placed, and then the method utilizes the frequency of their appearance as a means to infer the content of the document (Weber 1985).

\section{Design-build Industry Interviews}

The final research instrument consisted of structured interviews with design-builders to validate potential conclusions and effective practices found in study. The Government Accountability Office method states that structured interviews can be used where "information must be obtained from program participants or members of a comparison group... or when essentially the same information must be obtained from numerous people for a multiple case-study evaluation" (GAO 1991). Both these conditions apply to this study; therefore, the tool is appropriate for the research. 
Since geotechnical risk is often quantified in terms of cost, the above hypothesis was modified for the interviews to read:

The amount of the contingency for geotechnical risk varies inversely with the amount of site-specific geotechnical information that is provided to competing design-builders during procurement.

\begin{tabular}{|c|c|c|c|c|c|}
\hline \multicolumn{4}{|c|}{$\begin{array}{l}\text { DOT Respondents with } \\
\text { Design-build Experience }\end{array}$} & \multicolumn{2}{|c|}{$\begin{array}{l}\text { DOT Respondents without } \\
\text { Design-build Experience }\end{array}$} \\
\hline State & Position & State & Position & State & Position \\
\hline Alaska & $\begin{array}{l}\text { Construction } \\
\text { engineer }\end{array}$ & Nevada & $\begin{array}{l}\text { Geotechnical/ } \\
\text { foundations } \\
\text { engineer }\end{array}$ & Alabama & $\begin{array}{l}\text { Construction } \\
\text { engineer }\end{array}$ \\
\hline Arkansas & $\begin{array}{l}\text { Design project } \\
\text { manager }\end{array}$ & New Jersey & $\begin{array}{l}\text { Construction } \\
\text { engineer }\end{array}$ & Connecticut & $\begin{array}{c}\text { Geotechnical/ } \\
\text { foundations } \\
\text { engineer }\end{array}$ \\
\hline California & $\begin{array}{l}\text { Design project } \\
\text { manager }\end{array}$ & New Mexico & $\begin{array}{l}\text { Geotechnical/ } \\
\text { foundations } \\
\text { engineer }\end{array}$ & Illinois & $\begin{array}{l}\text { Design project } \\
\text { manager }\end{array}$ \\
\hline Colorado & $\begin{array}{c}\text { Design-build } \\
\text { project manager }\end{array}$ & $\begin{array}{c}\text { New } \\
\text { Hampshire }\end{array}$ & $\begin{array}{c}\text { Design project } \\
\text { manager }\end{array}$ & lowa & $\begin{array}{l}\text { Design project } \\
\text { manager }\end{array}$ \\
\hline Florida & $\begin{array}{l}\text { Construction } \\
\text { engineer }\end{array}$ & $\begin{array}{l}\text { North } \\
\text { Carolina }\end{array}$ & $\begin{array}{l}\text { Geotechnical/ } \\
\text { foundations } \\
\text { engineer }\end{array}$ & Kansas & $\begin{array}{l}\text { Construction } \\
\text { engineer }\end{array}$ \\
\hline Idaho & $\begin{array}{l}\text { Construction } \\
\text { engineer }\end{array}$ & North Dakota & $\begin{array}{l}\text { Design project } \\
\text { manager }\end{array}$ & Nebraska & $\begin{array}{l}\text { Design project } \\
\text { manager }\end{array}$ \\
\hline Indiana & $\begin{array}{l}\text { Geotechnical/ } \\
\text { foundations } \\
\text { engineer }\end{array}$ & Ohio & $\begin{array}{l}\text { Design project } \\
\text { manager }\end{array}$ & New York & $\begin{array}{l}\text { Design project } \\
\text { manager }\end{array}$ \\
\hline Kentucky & $\begin{array}{l}\text { Construction } \\
\text { engineer }\end{array}$ & Oregon & $\begin{array}{l}\text { Geotechnical/ } \\
\text { foundations } \\
\text { engineer }\end{array}$ & Oklahoma & $\begin{array}{l}\text { Construction } \\
\text { engineer }\end{array}$ \\
\hline Louisiana & $\begin{array}{l}\text { Geotechnical/ } \\
\text { foundations } \\
\text { engineer }\end{array}$ & $\begin{array}{l}\text { South } \\
\text { Carolina }\end{array}$ & $\begin{array}{l}\text { Design project } \\
\text { manager }\end{array}$ & Wyoming & $\begin{array}{l}\text { Design project } \\
\text { manager }\end{array}$ \\
\hline Maine & $\begin{array}{l}\text { Geotechnical/ } \\
\text { foundations } \\
\text { engineer }\end{array}$ & South Dakota & $\begin{array}{l}\text { Geotechnical/ } \\
\text { foundations } \\
\text { engineer }\end{array}$ & & \\
\hline Maryland & Materials engineer & Tennessee & $\begin{array}{l}\text { Construction } \\
\text { engineer }\end{array}$ & & \\
\hline $\begin{array}{l}\text { Massachu- } \\
\text { setts }\end{array}$ & $\begin{array}{l}\text { Design-build } \\
\text { project manager }\end{array}$ & Texas & Materials engineer & & \\
\hline Michigan & $\begin{array}{l}\text { Design-build } \\
\text { project manager }\end{array}$ & Utah & $\begin{array}{l}\text { Geotechnical/ } \\
\text { foundations } \\
\text { engineer }\end{array}$ & & \\
\hline Minnesota & $\begin{array}{l}\text { Geotechnical/ } \\
\text { foundations } \\
\text { engineer }\end{array}$ & Vermont & $\begin{array}{l}\text { Construction } \\
\text { engineer }\end{array}$ & & \\
\hline Mississippi & $\begin{array}{l}\text { Construction } \\
\text { engineer }\end{array}$ & Virginia & $\begin{array}{l}\text { Design-build project } \\
\text { manager }\end{array}$ & & \\
\hline Missouri & $\begin{array}{l}\text { Construction } \\
\text { engineer }\end{array}$ & Washington & Materials engineer & & \\
\hline Montana & $\begin{array}{c}\text { Design-build } \\
\text { project manager }\end{array}$ & & & & \\
\hline
\end{tabular}

Table 2 Survey respondent demographics

McLain, K et al (2014) 'Managing geotechnical risk on US design-build transport', Australasian Journal of Construction Economics and Building, 14 (1) 1-19 
Since it is impossible to know exactly how much contingency is being allocated to the perceived geotechnical risk, the researchers asked the entities that are at risk in a DB project for both the geotechnical design and the final project's construction to describe the impact on the proposed project contingency of the amount of geotechnical information that is available at the time a firm, fixed price must be submitted. The interviews were treated in the same manner as summary case studies because each set of interviewees had a unique perspective that was formed by the market in which it competed. Two primary criteria were established for selecting a designbuilder. First, the specific firm had to be one that had completed a DB project in at least one of the states that responded to the questionnaire. Secondly, it needed to have competed for at least one of the DB projects represented in the procurement document content analysis. Two secondary criteria were established for further filtering the pool of potential DB firms that qualified by the primary criteria, and those were to present a reasonably broad distribution of firms geographically and to have a sample that included small as well as large DB firms. Ultimately, interviews of 11 design-builders whose markets encompass over 30 states were conducted. They ranged in size from a regional bridge contractor that only worked in Utah to three national firms.

The following discussion reports the effective tools used by US state departments of transportation (DOT) to deal with the geotechnical conundrum described above and provides information on commonly used practices for managing geotechnical risks in DB projects.

\section{Analysis of the Survey and Content Analyses}

In traditional DBB construction projects, the design and construction are performed under two separate contracts. In many cases, the agency performs the design itself and then advertises for construction contractors to submit tender offers, termed "competitive bids" in US construction contracting jargon, on the construction documents. In DB, one entity takes on the responsibility for both design and construction. As a result, the agency on a DB project has less direct control over the day-to-day details of design development, as design is being done in conjunction with an awarded construction contract, which has fixed obligations to meet a schedule and a price. The analysis of the survey and content analysis strove to keep this fundamental difference in mind and seek effective practices that reconcile the design-builder's need to design to a fixed budget and contractual schedule with the agency's need to diligently oversee the geotechnical design process.

Table 3 contains the results of the content analysis and the survey responses regarding the amount of geotechnical information contained in typical DB RFPs. The FHWA Report to Congress on DB effectiveness (Federal, 2006) differentiated between the survey responses of those agencies that had completed 5 or more DB projects and those with less experience. Using the FHWA study's approach, this study's results were split by the number of DB projects the agency had completed to differentiate between agencies that were relatively new to DB and those with multi-project experience. The table shows that experienced agencies furnish more information than inexperienced agencies. The literature exposed one possible reason for the difference. There is a school of thought that maintains that furnishing specific geotechnical data in a DB project assigns all the risk of DSC to the client, and as such guarantees a DSC claim (Loulakis and Shean, 1996). Table 2 would seem to support this notion since the inexperienced agencies consistently include less information than the more experienced agencies. Taking the WSDOT (2006) policy discussed in the literature review above with Table 2 and remembering that the design-builder will probably complete the geotechnical investigations as part of the design process leads to the conclusion that furnishing as much geotechnical information as is available at the time the project is advertised effectively mitigates the risk by providing a clear

McLain, K et al (2014) 'Managing geotechnical risk on US design-build transport', Australasian Journal of Construction Economics and Building, 14 (1) 1-19 
definition of the site conditions at the time competitive proposals were submitted rather than hoping to avoid a claim by not furnishing any information.

\begin{tabular}{|l|c|c|c|c|}
\hline \multirow{2}{*}{$\begin{array}{l}\text { Geotechnical Information Included } \\
\text { in DB RFP } \\
\text { (in ascending level of detail) }\end{array}$} & \multicolumn{2}{|c|}{$\begin{array}{c}\text { Percentage of the Total of } \\
\text { All RFP Observations }\end{array}$} & $\begin{array}{c}\text { Percentage of the Total of } \\
\text { All Survey Responses }\end{array}$ \\
\cline { 2 - 5 } & \multicolumn{2}{|c|}{ RFP Content Analysis } & \multicolumn{2}{|c|}{ DOT Survey } \\
\cline { 2 - 5 } & $\begin{array}{c}\text { DOTs with } \\
\text { less than 5 } \\
\text { DB projects }\end{array}$ & $\begin{array}{c}\text { DOTs with 5 } \\
\text { or more DB } \\
\text { projects }\end{array}$ & $\begin{array}{c}\text { DOTs with } \\
\text { less than 5 } \\
\text { DB projects }\end{array}$ & $\begin{array}{c}\text { DOTs with 5 } \\
\text { or more DB } \\
\text { projects }\end{array}$ \\
\hline Reconnaissance Report & $3 \%$ & $8 \%$ & $0 \%$ & $7 \%$ \\
\hline Geotechnical Data Report & $11 \%$ & $26 \%$ & $7 \%$ & $22 \%$ \\
\hline Geotechnical Summary Report & $8 \%$ & $13 \%$ & $4 \%$ & $11 \%$ \\
\hline $\begin{array}{l}\text { Preliminary Geotechnical Design } \\
\text { Report }\end{array}$ & $3 \%$ & $21 \%$ & $9 \%$ & $11 \%$ \\
\hline Geotechnical Design Report & $5 \%$ & $0 \%$ & $4 \%$ & $11 \%$ \\
\hline Geotechnical Baseline Report & $0 \%$ & $3 \%$ & $2 \%$ & $11 \%$ \\
\hline
\end{tabular}

Table 3 RFP content analysis and DOT survey results regarding DB RFP geotechnical content

\section{Managing Pre-award Geotechnical Uncertainty}

Uncertainty, by definition, is a lack of information. Geotechnical uncertainty is reduced as site investigations, test reports, and geotechnical engineering is completed. In DB, geotechnical uncertainty is high during the procurement phase, and the client's primary tool to mitigate risk is through selecting a competent design-builder with the requisite experience to complete the design and construction.

Evaluation criteria are typically found in both the RFQ and the RFP, and can be expressed as standards for the qualifications of key geotechnical personnel, past experience on projects with similar geotechnical issues, and technical criteria for the proposed geotechnical design and construction approach. In the solicitation document content analysis, 37 of 46 of the project documents had some form of evaluation criteria for geotechnical factors explicitly listed in the document. Of those 37 projects, over two-thirds evaluated the qualifications of the project's geotechnical personnel. Next, 62\% evaluated the design-build firm's past experience designing and building projects with similar geotechnical requirements. Slightly over one-third included geotechnical evaluation criteria in the technical and/or price evaluation plan. In the survey, 94\% of experienced and $53 \%$ of inexperienced respondents evaluated the qualifications of the design-builder's project geotechnical personnel. Past geotechnical experience was rated at $65 \%$ and $33 \%$ respectively. In $53 \%$ of the experienced DOT responses local experience was also rated with only $20 \%$ of the inexperienced DOTs asking for that information. This data leads to the conclusion that evaluating the geotechnical-specific qualifications, experience, and technical approach is an effective means to manage pre-award geotechnical risk by requiring wellqualified personnel, firms with a record of successfully completing DB projects with geotechnical issues, and an understanding of the design-builder's approach to solving geotechnical issues prior to DB contract award.

Allowing alternative technical concepts (ATC) to be proposed is a third method for dealing with pre-award geotechnical risk. ATCs furnish a means to "seek innovation from the private sector to reduce project costs and add technical enhancements" (Papernik and Farkas, 2011) without giving up control of the design process. Figure 1 is a compilation of the results from each research instrument. The fact that $71 \%$ of the experienced agencies included geotechnical

McLain, K et al (2014) 'Managing geotechnical risk on US design-build transport', Australasian Journal of Construction Economics and Building, 14 (1) 1-19 
ATCs in their DB projects testifies to the effectiveness of this particular practice. An Australian study found that the "road industry had the greatest propensity to invest in [research]... [and was] able to expertly judge the value of innovation ideas proposed by the industry" (Manley and McFallan, 2006), which validates the US observations in Figure 1. ATC procedures typically include the use of confidential "one-on-one" meetings with each competitor where, in addition to offering ATCs, the DB team can also seek clarifications of RFP content. These meeting are called "proprietary meetings" by some agencies that permit competing design-builders to clarify RFP intent and ask questions that might lead to the submission of an ATC. The overall effect of meetings is to reduce the uncertainty with regard to interpreting geotechnical evaluation criteria and to permit the design-builders to offer solutions to geotechnical design problems with which they are more confident. In theory, this process should lead to reduced contingencies in the price (Christensen and Meeker, 2002).

\section{ATCs Allowed}

Solicitation Document Content Analysis

Survey: DOT with > 5 DB Projects

DB Guidelines Content Analysis



Survey: DOT with < 5 DB Projects

0\% $10 \%$ 20\% 30\% 40\% 50\% 60\% 70\% 80\%

Figure 1 Research instrument output regarding alternative technical concept use

An example of just how valuable the confidential ATC process can be was found in a DB project in Minnesota. This particular project involved replacing a bridge over the Mississippi River at Hastings. The foundation on the north side of the river rested on extremely poor alluvial soils that resulted in the need to jack the existing bridge up nearly 46 centimetres over its 30-year service life (Molenaar et al. 2012). The original engineer's estimate was about US $\$ 220.0$ million. The DB RFP for the project included a "performance criterion of less than 2 inches [5 centimetres] of total settlement complete within three months of embankment construction" (Minnesota, 2010). The winning DB contractor proposed a confidential ATC to found the north approach on a "column-supported fill," a technical approach that had not yet been tried in North America (Molenaar et al. 2012). The ATC also offered to furnish and install instrumentation to monitor actual settlement over time as well as a three-year, instead of a 3-month, warranty against differential settlement. The contract was awarded at approximately US $\$ 130.0$ million, and roughly US $\$ 80.0$ million could be ascribed to the reduction in geotechnical risk by the approved ATC (Molenaar et al. 2012). While this is an extreme example of using confidential one-on-one meetings with competing DB contractors to mitigate pre-award geotechnical risk, it

McLain, K et al (2014) 'Managing geotechnical risk on US design-build transport', Australasian Journal of Construction Economics and Building, 14 (1) 1-19 
amply demonstrates that furnishing a mechanism where new ideas can be considered and clarifications to RFP requirements can be sought has the potential to accrue real cost and time savings to the public client.

\section{Mitigating Post-Award Geotechnical Risk}

The fact that US public transport agencies typically select DB to accelerate project delivery (Federal, 2006) limits the amount of pre-award geotechnical investigation an agency can do and, hence, makes post-award agency design approval a major hurdle to starting construction (Christensen and Meeker, 2002). Therefore, the geotechnical design package must be completed as expeditiously as possible (Koch et al., 2010), permitting the agency to reduce the impact of geotechnical risk as expeditiously as possible after award (Kim et al., 2009). Hence, the geotechnical design review process can act as either a barrier to releasing geotechnical design packages for construction or a conduit that facilitates the early discovery and resolution of significant geotechnical design issues.

The literature review found that the number of required design reviews by the clients varies across the US. However, NCHRP Synthesis 376 (Gransberg et al., 2008) identified three main approaches, and its DB RFP content analysis showed the percentages of use:

- No formal review prior to final (release-for-construction) design review (15\%),

- One review prior to the final design review (56\%),

- Multiple reviews prior to the final design review (29\%).

The fact that $71 \%$ of those projects had one or no intermediate design reviews prior to the final review is noteworthy. In those cases, the agencies still provided oversight and informal comments, but made a concerted effort to not delay the design-builder's progress by imposing its design preferences for the project via multiple review and comment processes.

In many of the documents reviewed in the content analysis, the design-builder is directed to request informal reviews that allow the client to provide more frequent input to ensure that the final design will meet the contract requirements. These reviews are often called "over-theshoulder" or "oversight" reviews to indicate that the design process will not stop to wait for comments from the informal review process. The primary issue when using this process is for the agency to demonstrate that it has discharged its statutory responsibility of "due diligence." The Arizona DOT follows a procedure described as follows:

"Over-the-shoulder-reviews are performed while the design is being developed. They are proactive in nature, informal, interactive, and intended to catch omissions and oversights that may lead to a major redesign of the work" (Arizona, 2001).

Arizona also uses a design review procedure that is uniquely well-suited to geotechnical design deliverables. It is called the "early construction review" and is reserved for design product that will be released for construction before the design is $100 \%$ complete. "The intent is to ensure that enough detail has been provided in the plans to allow construction to begin and that ADOT's minimum design standards are maintained" (Arizona, 2001). This process reinforces the due diligence requirements and allows the agency to obtain the necessary level of comfort with the design quality of early geotechnical features of work scheduled in support of achieving an aggressive project delivery period. Table 4 contains the result of the content analysis for this topic. It shows that experienced agencies are comfortable with the use of a non-traditional design process to supplement the final review. 


\begin{tabular}{|l|c|c|}
\hline Design Review Types & DOT $<\mathbf{5}$ DB Projects & DOT $\geq \mathbf{5}$ DB Projects \\
\hline Single or multiple design reviews before final & 5 & 9 \\
\hline Over-the-shoulder & 1 & 17 \\
\hline Optional early design reviews & 3 & 12 \\
\hline
\end{tabular}

Table 4 Content analysis design review output

The design-builder interviewees were asked to rate the impact of a number of components to the DB design process on the quality of the final constructed geotechnical features. The majority $(67 \%)$ felt that the use of geotechnical performance criteria/specifications had a major impact and over half cited being given detailed design criteria also promoted design and construction quality. A majority cited multiple design reviews (7 of 11), sequential design reviews by different agency design personnel ( 8 of 11), and the agency personnel's willingness to accept over-theshoulder design reviews ( 9 of 11 ) as challenges to timely completion that could potentially negatively impact quality on all DB projects.

The required use of agency-mandated geotechnical specifications and design details on DB projects reduces the agency's need to be involved during the actual design process. This then permits the expeditious review of geotechnical engineering products and facilitates the use of design oversight practices such as the over-the-shoulder review. The literature (Higbee, 2004; Christensen and Meeker, 2002; Papernik and Farkas, 2011) and the agency DB guidelines (Washington, 2004; Department, 2010; Arkansas, 2006) promote the concept that prescriptive design requirements in the DB process limits the ability of the design-builder to innovate. However, obtaining innovative design solutions requires the agency to spend the time necessary to satisfy its statutory due diligence requirements, which could potentially create schedule delay nullifying the benefits gained from the innovative design (Koch et al. 2010).

\section{Impact of Geotechnical Risk Management Practices on Project Quality}

All the above discussion is ultimately about controlling the quality of the constructed final product. The DOT survey and design-builder interviews asked the respondents to gauge the impact on quality of a list of project factors. Table 5 shows that both the clients and the industry agree that geotechnical qualifications and experience have the most impact. They also agree on the benefits of involving the contractor in the design process and the value of performance criteria. The major difference is the perception of the value of agency involvement during the proposal phase. This correlates to the use of one-on-one meetings to clarify RFP requirements and to propose ATCs. Obviously the design-builders appreciate the opportunity to ask questions and clarify ambiguities before they have to submit a lump sum proposal for a multi-million dollar project. The other disconnect regards the perceived value of geotechnical quality management plans. Again the design-builders felt the plans had a much higher impact on final quality than the agency respondents. Since these are typically submitted in part in the proposal and in full after award before work begins, the industry perception may be due to the fact that the review and approval process further clarifies and quantifies the clients' expectations with regard to final geotechnical requirements. The results of this analysis lead to the conclusion that the use of proposal phase one-on-one discussions and post-award development and agreement on quality management plans are effective geotechnical risk management practices. In essence, the analysis argues that the geotechnical quality management system be similar to that used in DBB and probably different than the quality management system that will apply to the rest of the DB project.

McLain, K et al (2014) 'Managing geotechnical risk on US design-build transport', Australasian Journal of Construction Economics and Building, 14 (1) 1-19 


\begin{tabular}{|l|c|c|c|c|c|c|}
\hline \multicolumn{1}{|c|}{ Research Instrument } & \multicolumn{3}{|c|}{ DOT Survey } & \multicolumn{2}{c|}{ Design-builder Interviews } \\
\hline \multicolumn{1}{|c|}{ Factor } & $\begin{array}{c}\text { Very/High } \\
\text { Impact }\end{array}$ & $\begin{array}{c}\text { Some/ } \\
\text { Slight } \\
\text { Impact }\end{array}$ & $\begin{array}{c}\text { No } \\
\text { Impact }\end{array}$ & $\begin{array}{c}\text { Very/High } \\
\text { Impact }\end{array}$ & $\begin{array}{c}\text { Some/ } \\
\text { Slight } \\
\text { Impact }\end{array}$ & $\begin{array}{c}\text { No } \\
\text { Impact }\end{array}$ \\
\hline $\begin{array}{l}\text { Qualifications of the Design- } \\
\text { Builder's geotechnical staff }\end{array}$ & $89 \%$ & $11 \%$ & $0 \%$ & $91 \%$ & $9 \%$ & $0 \%$ \\
\hline $\begin{array}{l}\text { Design-Builder's past geotechnical } \\
\text { project experience }\end{array}$ & $85 \%$ & $15 \%$ & $0 \%$ & $82 \%$ & $18 \%$ & $0 \%$ \\
\hline $\begin{array}{l}\text { Agency interactivity with } \\
\text { geotechnical design team during } \\
\text { proposal phase }\end{array}$ & $26 \%$ & $48 \%$ & $26 \%$ & $73 \%$ & $27 \%$ & $0 \%$ \\
\hline $\begin{array}{l}\text { Early contractor involvement in } \\
\text { geotechnical design }\end{array}$ & $63 \%$ & $37 \%$ & $0 \%$ & $73 \%$ & $27 \%$ & $0 \%$ \\
\hline $\begin{array}{l}\text { Use of geotechnical performance } \\
\text { criteria/specifications }\end{array}$ & $67 \%$ & $19 \%$ & $15 \%$ & $64 \%$ & $36 \%$ & $0 \%$ \\
\hline $\begin{array}{l}\text { Level of agency involvement in the } \\
\text { geotechnical QA process }\end{array}$ & $37 \%$ & $56 \%$ & $7 \%$ & $55 \%$ & $45 \%$ & $0 \%$ \\
\hline $\begin{array}{l}\text { Use of agency specifications and/or } \\
\text { design details }\end{array}$ & $67 \%$ & $33 \%$ & $0 \%$ & $45 \%$ & $45 \%$ & $10 \%$ \\
\hline $\begin{array}{l}\text { Level of detail expressed in the } \\
\text { procurement documents }\end{array}$ & $63 \%$ & $33 \%$ & $4 \%$ & $45 \%$ & $45 \%$ & $10 \%$ \\
\hline \begin{tabular}{l} 
Quality management plans \\
\hline Warranty provisions
\end{tabular} & $41 \%$ & $56 \%$ & $4 \%$ & $82 \%$ & $18 \%$ & $0 \%$ \\
\hline
\end{tabular}

Table 5 Impact on final project quality

\section{Comments and Conclusions}

The study sought to answer research questions on managing pre-award geotechnical risk and mitigating/retiring that risk expeditiously after award. The survey, the content analyses, the interviews, and the literature provided a rich source of information from which to draw conclusions and answer the research questions.

Experience has shown that the most effective approach to managing pre-award risk is to conduct a thorough geotechnical investigation before awarding the construction. However, the combination of pressure to expedite project delivery by the federal government and financial incentives to implement DB increase the potential that state DOTs will tackle major projects with thorny geotechnical issues using DB. Ultimately, the issue becomes whether or not the client is willing to pay via the design-builder's contingencies for geotechnical risks that may go unrealized. Therefore, the primary finding is a strong recommendation that an agency use extreme caution before selecting DB project delivery on a project involving high geotechnical risk.

Given that recommendation, if an agency finds it must deliver such a project using DB, it must then aggressively manage geotechnical risk in an expeditious manner to achieve cost, schedule, and construction quality goals. To that end the following conclusions that answer the first research question are offered:

- US DOTs consider DB to be an effective tool for accelerating project delivery.

- Achieving an aggressive schedule requires that the geotechnical design be completed as soon as practical to avoid delaying the start of construction. 
US state DOTs manage geotechnical risk during the pre-award phase through RFP requirements:

- for well qualified and experienced geotechnical personnel;

- by limiting potential geotechnical design solutions to ones with which the agency has previous experience.

A number of effective geotechnical risk management tools were also identified.

- Agency interactivity during the proposal phase had a high or very high impact on final project quality.

- Communication with competing design-builders is enhanced during proposal preparation phase by using confidential one-on-one meetings to clarify RFP intent, resolve ambiguities in the RFP geotechnical data, and to present potential geotechnical ATCs.

- Confidential ATCs create a mechanism for competing design-builders to clarify the magnitude of the geotechnical risk before quantifying it in the price proposal.

- The use of risk sharing clauses that quantify in dollar terms the geotechnical risk a design-builder is exposed to with the agency assuming responsibility for differing conditions cost above that threshold was found to be an effective practice.

In answer to the second research question, effective tools to retire geotechnical risk after award by expediting design review are as follows:

- Minimize the number of interim design reviews before the final release for construction acceptance review of geotechnical design.

- Maximize the use of both formal and informal over-the-shoulder geotechnical design reviews to resolve issues and concerns as they arise rather than stopping the design production by requesting a complete package and a period in which the design-builder cannot move forward until comments are received and addressed.

- Permit the release of geotechnical design packages for construction before the remainder of design is complete to begin excavation to identify and resolve any differing conditions as soon as practical.

The final effective practice is crafting explicit DSC clauses that permit expeditious resolution of discrepancies between pre-award and post-award geotechnical conditions. The research found that furnishing all the geotechnical information on hand when the project is advertised and building the DSC clause in a manner that makes it specific to the available geotechnical data rather than merely using a standard boilerplate DSC found in DBB projects was an effective alternative.

The above conclusions are limited in their application to the US markets from which the data was drawn. Because there are significant differences in contracting laws and regulations internationally, the reader is cautioned against generalizing these conclusions without thoroughly reviewing the applicable legal environment in which the conclusions may seem to apply. Nevertheless, geotechnical risk is inherent to all projects regardless of location. Thus, the effective practices that relate to the expeditious review of geotechnical design product to accelerate the ability to begin excavation and determine actual site conditions as soon as practical could be generalised to all DB projects. 
The conclusions do support a common theme regarding managing geotechnical risk in DB projects. The public agency can best manage these risks by creating an environment of information-rich communications with its industry partners before the procurement starts, during the procurement process itself, and after award of the DB contract. Clearly, there is no "magic" contract clause that can adequately absolve the public agency of geotechnical risk. Therefore, actively managing risk and expediting the identification, quantification, and resolution of geotechnical risk is in the best interest of the agency and the design-builder, as well as the taxpayer that ultimately must pay the bills.

\section{References}

Arizona Department of Transportation (2001) Design-Build Procurement and Administration Guide, 2nd Edition, Arizona DOT Construction Group, Phoenix, AZ.

Arkansas State Highway and Transportation Department (2006) Design-Build Guidelines and Procedures, ASHTD Little Rock, AR.

Baecher, G.B., (1987) Geotechnical Risk Analysis User's Guide. Federal Highway Administration Report RD-87-011, US Department of Transportation, Federal Highway Administration, Washington, D.C., 50.

Baynes, F.J. (2010) 'Sources of geotechnical risk', Quarterly Journal of Engineering Geology and Hydrogeology, 43, 321-331.

Blanchard, B., (2007) 'Design-build lessons learned Florida DOT', Proceedings Louisiana Transportation Engineering Conference, 12-14 March, Baton Rouge, LA, 6-14.

California Department of Transportation (2010) Design-Build Demonstration Program, Sacramento, CA. [Online] Available: http://www.dot.ca.gov/hq/oppd/designbuild/db.htm [October 30, 2012].

Centennial Contractors, Inc. (2004) Design-Build Project Manual, Centennial Contractors, Inc., Vienna, Virginia, 137.

Christensen M.R. and Meeker, L.E. (2002) 'Design-build projects - lessons learned from the contractor's perspective', Proceedings American Railway Engineering and Maintenance-of-Way Association, 3-9 December, Lanham, MD, 14.

Clark, G.T. and Borst A. (2002) 'Addressing risk in Seattle's underground', PB Network, January, 34-38.

Department of Defense. (2010) Unified Facilities Criteria (UFC), UFC 1-300-09N 25 May 2005 Including Change 7, Washington, DC.

Design-Build Institute of America (2013) 2013 Design-build state laws for transportation procurement, [online] Available at: http://www.dbia.org/NR/rdonlyres/231CFB85-2483-4D8A87DF-BF72193C61D7/0/tran130103.pdf [February 2, 2013].

Diekmann, J.E., Songer, A.D. and Pecsok, R.S. (1987) 'Risk analysis for revenue dependent infrastructure projects', Journal of Construction Management and Economics, 15 (4), 377-382.

Dwyre, E.M., Batchko, Z. and Castelli, R.J. (2010) 'Geotechnical baseline reports for foundation projects', Proceedings GeoFlorida 2010: Advances in Analysis, Modeling \& Design (GSP 199), 21-25 August, Orlando, FL, 1-10.

Ernzen, J. and Feeney, T. (2002) 'Contractor-led quality control and quality assurance plus design-build: who is watching the quality?', Transportation Research Record, 1813, Transportation Research Board of the National Academies, 253-259.

McLain, K et al (2014) 'Managing geotechnical risk on US design-build transport', Australasian Journal of Construction Economics and Building, 14 (1) 1-19 
Federal Highway Administration (2006). Design-build effectiveness study - as required by TEA21 Section 1307(f): final report, US Department of Transportation, Federal Highway Administration, Washington, DC.

Federal Highway Administration, (2013) MAP-21: Moving Ahead for Progress in the 21st Century, [online] Available at: http://www.fhwa.dot.gov/map21/ [February 2, 2013].

Federal Register, (2007) Design-build contracting, Final Rule, Rules and Regulations, 72 (156), August 14, 2007, 45329.

Florida Department of Transportation (2011) Alternative technical concepts reviews, FDOT Design-build Guidelines, 2, 21-27.

Government Accountability Office (GAO) Using Structured Interviewing Techniques, 7 GAO/PEMD-10.1.5, Government Accountability Office, Washington, D.C., June 1991, 191

Gransberg, D.D., K.R. Molenaar, and J.N. Datin. (2008) Quality Assurance in Design-Build Projects, NCHRP Synthesis 376, Transportation Research Board National Academies, Washington, DC, 39-42.

Gransberg D.D. and Loulakis, M.C. (2012) Geotechnical Information Practices in Design-Build Projects, Synthesis 429, Transportation Research Board, National Academies, Washington, DC.

Hatem, D.J., (2011) 'Risk allocation for subsurface conditions and defective design', Brierley, G.S. Corkum D.H. and Hatem, D. J.(eds), Design-Build Subsurface Projects, Society for Mining, Metallurgy and Exploration, Englewood, CO, 22-28.

Higbee, J.B., (2004) 'Geotechnical issues with large design-build highway projects', Transportation Research Record, 1868, TRB, National Research Council, Washington, DC, 147-153.

Ho, K. K. S., Leroi, E., \& Roberds, W. J. (2000) 'Quantitative risk assessment: application, myths and future direction', Proceedings International Conference on Geotechnical \& Geological Engineering, GeoEng, London, 14-19 July, 269-312.

Hung, C.J., Monsees, J., Munfah, N. and Wisniewski, J. (2009) Technical Manual for Design and Construction of Road Tunnels - Civil Elements, Technical Report FHWA-NHI-10-034, National Highway Institute, New York, 35-87.

Jaksa, M. B. (2000) 'Geotechnical risk and inadequate site investigations: A case study', Australian Geomechanics, 35 (2), 39-46.

Jordan, E., Gross, M. E., Javernick-Will, A. N., \& Garvin, M. J. (2011) 'Use and misuse of qualitative comparative analysis', Construction Management and Economics, 29 (11), 11591173.

Kim, K.J., Kreider, C.A., and Valiquette, M.D. (2009) 'North Carolina Department of Transportation's practice and experience with design-build contracts geotechnical perspective', Transportation Research Record, 2116, Transportation Research Board of the National Academies, Washington, D.C., 47-52.

Koch, J.E., D.D. Gransberg, and K.R. Molenaar. (2010) Project Administration for Design-Build: A Primer for Owners, Engineers, and Contractors, ASCE Press, Reston, VA, 118-145.

Loulakis, M.C. and Shean, O. J. (1996) Risk transference in design-build contracting. Construction Briefings, 2nd series, Federal Publications, Washington, DC, 12.

Loulakis, M.C., Wagner, B.P. and Splan, H.C., (1995) 'Differing site conditions', R.S. Brams and C. Lerner, Construction Claims Deskbook, Aspen Law and Business, New York, 1995, 131166.

McLain, K et al (2014) 'Managing geotechnical risk on US design-build transport', Australasian Journal of Construction Economics and Building, 14 (1) 1-19 
Mahdi, I.M., Alreshaid, K. (2005) 'Decision support system for selecting the proper project delivery method using analytical hierarchy process', International Journal of Project Management, 23, 564-572.

Manley, K. and McFallan, S. (2006) 'Exploring the drivers of firm-level innovation in the construction industry', Construction Management and Economics, 2 (9), 911-920.

Mendez, V., (2010) Every day counts: innovation initiative, Federal Highway Administration, Washington, DC, 1-2.

Minnesota Department of Transportation (2003) Approach to alternative technical concepts, MnDOT Design-Build Program White Paper No. MN-11, St Paul, MN. 1.

Minnesota Department of Transportation (2010) Request for Proposals, Book 1 - TH 61 Hastings Bridge Design-Build Project S.P. 1913-64, Minnesota DOT, Metro District, St. Paul, MN, 7.

Mississippi Department of Transportation (2005) Request for Proposals, Addendum 1, A Design-Build Project Bridge Replacement on US 90 Biloxi to Ocean Springs Bridge Jackson and Harrison Counties, Mississippi, Contract No. ER/BR-0003-01(099) 104556/301000 Biloxi/Ocean Springs Bridge, Jackson, MS.

Molenaar, K.R., Gransberg, D.D., West, N.J.N. and Kraft, E. (2012) Alternative Quality Management Systems for Highway Construction, National Cooperative Highway Research Program Report 10-83, Transportation research Board of the National Academies, Washington, D.C. 121-124.

Neuendorf, K.A. (2002), The Content Analysis Guidebook, Sage Publications, Thousand Oaks, CA, 216.

Oberguggenberger, M., and W. Fellin (2002) 'From probability to fuzzy sets: the struggle for meaning in geotechnical risk assessment', Conference Report, 1-10.

Oppenheim, A. N. (1992) Questionnaire Design, Interviewing and Attitude Measurement, 24 Continuum, London.

Papernik, B.G. and Farkas, D.J. (2011) Using alternative technical concepts to improve designbuild and PPP procurements, Nossaman E-Alerts, [Online] Available: http://www.nossaman.com/using-alternative-technical-concepts-improve-designbuild-ppp, [May 26, 2011].

Perkins, R.A. (2009) 'Sources of changes in design-build contracts for a governmental owner', Construction Engineering and Management, 135 (7), 32-41.

Salter, A. and Torbett, R. (2003) Innovation and performance in engineering design, Journal of Construction Management and Economics, 21, 573-580.

Smith, R. (2008) 'An evolving view of geotechnical engineering - a focus on geo-risk management', Geotechnical Special Publication No. 178, GeoCongress 2008: New Orleans, LA, 231-239.

Songer, A.D. and Molenaar, K.R. (1996) 'Selecting design-build: private and public sector owner attitudes', Management in Engineering, 12 (6), 47-53.

Texas Turnpike Authority (2001) Request for proposals to construct, maintain and repair the SH 130 turnpike through an exclusive development agreement, Texas Department of Transportation, Austin, TX.

Tufenkjian, M., (2007) Review of geotechnical services, California Department of Transportation, Final Report, USDOT Federal Highway Administration, Washington, D.C., 76.

McLain, K et al (2014) 'Managing geotechnical risk on US design-build transport', Australasian Journal of Construction Economics and Building, 14 (1) 1-19 
van Staveren, M.T. (2007) 'Extending to geotechnical risk management', ISGSR2007, 1st International Symposium on Geotechnical Safety and Risk, 22-26 June, Shanghai, 1-12.

Washington State Department of Transportation (2004) Guidebook for Design-build Highway Project Development, Washington State Department of Transportation, Olympia, WA.

Weber, R.P. (1985) Basic Content Analysis, Sage Publications, Beverly Hills, CA. 